IZA DP No. 4861

Training Subsidies and the Wage Returns to Continuing Vocational Training: Evidence from Italian Regions

Giorgio Brunello

Simona Comi

Daniela Sonedda

April 2010 


\title{
Training Subsidies and the Wage Returns to Continuing Vocational Training: Evidence from Italian Regions
}

\author{
Giorgio Brunello \\ University of Padova, \\ CESifo and IZA \\ Simona Comi \\ University of Milan Bicocca \\ and CHILD \\ Daniela Sonedda \\ University of Piemonte Orientale \\ and CRENOS \\ Discussion Paper No. 4861 \\ April 2010 \\ IZA \\ P.O. Box 7240 \\ 53072 Bonn \\ Germany \\ Phone: +49-228-3894-0 \\ Fax: +49-228-3894-180 \\ E-mail: iza@iza.org
}

Any opinions expressed here are those of the author(s) and not those of IZA. Research published in this series may include views on policy, but the institute itself takes no institutional policy positions.

The Institute for the Study of Labor (IZA) in Bonn is a local and virtual international research center and a place of communication between science, politics and business. IZA is an independent nonprofit organization supported by Deutsche Post Foundation. The center is associated with the University of Bonn and offers a stimulating research environment through its international network, workshops and conferences, data service, project support, research visits and doctoral program. IZA engages in (i) original and internationally competitive research in all fields of labor economics, (ii) development of policy concepts, and (iii) dissemination of research results and concepts to the interested public.

IZA Discussion Papers often represent preliminary work and are circulated to encourage discussion. Citation of such a paper should account for its provisional character. A revised version may be available directly from the author. 


\section{ABSTRACT \\ Training Subsidies and the Wage Returns to Continuing Vocational Training: Evidence from Italian Regions ${ }^{\star}$}

We use the variation of training policy over time and across Italian regions to identify the relationship between individual training and earnings. Using longitudinal data for the period 1999 to 2005, we find that the marginal effect of one additional week of formal training on monthly earnings is 4.4 percent. This effect declines rapidly over time and is equal to 0.86 percent 10 years after the investment. We also find that marginal returns are higher among small firms, which are more likely to be constrained by lack of economic resources in their training decisions. Since small firms train less than large firms, their higher returns from the training induced by training policies can simply reflect decreasing marginal returns to training.

JEL Classification: J24

Keywords: training, training policies, Italy

Corresponding author:

Giorgio Brunello

Department of Economics

University of Padova

Via del Santo 33

35100 Padova

Italy

E-mail: giorgio.brunello@unipd.it

\footnotetext{
* We are grateful to Andrea Bassanini, Erich Battistin, Lorenzo Cappellari, Daniele Checchi, Maria De Paola, Carlo Devillanova, Margherita Fort, Luciano Greco, Michele Pellizzari, Enrico Rettore, Simone Sarti and the to audiences at seminars in Milan (Mills), Novara, Padova (Bomopa) and Trento (Irvapp) for comments and advice. We also thank Luigi Accogli of ISFOL and Antonio Schizzerotto for providing some of the data used in this paper. The ILFI dataset (Indagine longitudinale sulle famiglie italiane, 1997-2005) is produced by Università di Milano Bicocca, Università degli Studi di Trento, Università degli Studi di Bologna (scientific coordinator: A. Schizzerotto). The usual disclaimer applies.
} 
$\underline{\text { Introduction }}$

There is broad consensus among policy makers that training is important for employment, productivity and individual well - being. Yet applied economists have long recognized that estimating the wage returns to training is complicated by the fact that selection into training is not random, and that assignment to training is correlated with unobserved individual ability. Since ability affects earnings, a simple regression of earnings on training fails to identify a causal effect. The predominant approach adopted by the empirical literature so far has been to use a fixed effects estimator to correct for time invariant unobserved heterogeneity.

Approaches based on instrumental variables have not been as popular, mainly because it is difficult to find plausible exclusion restrictions (Frazis and Lowenstein, 2006; Lee, 2005). Yet theoretical models provide some guidance for the selection of instruments. For instance, a property of the by now standard model of training in imperfect labour markets by Acemoglu and Pischke, 1999, is that training subsidies affect training directly but wages and the probability of employment only indirectly, via their effects on training. In this paper, we exploit this property and use regional training policy - which consists of planned training subsidies and grants - to study the causal effect of training on the earnings. We consider only formal and continuing vocational training, which takes place after completion of full time education and labour market entry.

By planned subsidies we mean the invitations to tender issued by regional governments and the resources allocated for training expenditures in regional budgets. Compared to actual training expenditures, which are affected by the decisions of individuals and firms, planned expenditures are more likely to reflect regional training policies.

Regional training policies in support of continuing vocational training have been implemented in Italy since the mid 1990s, when Objective 4 of the European Training Fund (budget period 1994-1999) introduced measures to help workers adapt to industrial change and to changes in production systems. This measures included vocational education, re-training, guidance and counselling, and affected Italian regions differently, because the Southern regions covered by Objective 1 
were excluded. Starting with 1997, Italian national law added new measures in support of training (Laws 236 and 53), which were funded by payroll taxes and managed with increasing autonomy by regional governments.

The different policy priorities of each region, as well as the differences in the ability to spend available resources - especially between the North and the South of Italy - have generated significant variations both across regions and over time in the real resources per head allocated to continuing vocational training. We exploit these variations to estimate the wage returns to training in Italy during the years 1999 to 2005.

We collect data on Italian regional training policies from their onset in 1994 to 2005 and compute for each region and year the cumulated sum of real planned training subsidies per head. We merge these data with a longitudinal dataset which covers the years 1999, 2001, 2003 and 2005 and provides information on individual monthly earnings, the number of formal training episodes experienced during the relevant reference period and a rich set of individual controls. We use this and retrospective information to compute a measure of individual training stock that is more satisfactory than the simple measure of training incidence which is often used in this literature.

We instrument this stock in a standard earnings function with the (lagged) sum of real planned subsidies per head. We find that regional training policy has a positive and statistically significant effect on the individual training stock. There is also evidence that the selected instrument is not weak. However, the size of the estimated effect is small: we find that one additional real euro per head devoted to training subsidies by regional governments from 1994 to year t-1 has increased the discounted training stock in year t by 0.61 to 0.68 percent, depending on the specification. Ceteris paribus, these estimates suggest that in order to increase the average training stock by 10 percent, regional governments would have to allocate to training incentives an additional sum of 17 real euros per head, a 30.8 percent increase with respect to the sample average.

When we treat the training stock as exogenous, we find that adding one week of training in year $t$ increases average monthly earnings in the same year by 0.5 to 0.7 percent, depending on the specification. When we instrument the training stock with 
the (lagged) stock of training grants, we find that the marginal effect of a week of training on current earnings is much higher, and ranges between 3.5 and 4.4 percent. However, this effect declines rapidly over time and is about 20 percent of its initial value ten years after the investment. When we consider a 20 years period, the average marginal return to an additional week of formal training is at most 1.35 percent.

These estimated returns are local average treatment effects and suggest that the individuals who change their training because of changes in training grants enjoy relatively high returns that dissipate rapidly over time. We ask whether these returns vary with observable characteristics, such as age, education, gender and firm size, and find evidence that they are significantly higher for the employees of small firms (with less than 100 employees). Small firms typically train less than large firms, because they lack the resources or the necessary facilities (see Bassanini et al, 2007). Since the marginal returns to training decline with the quantity invested, additional investments induced by training subsidies are bound to pay off more at the margin for workers of small firms.

The paper is organized as follows. Section 1 briefly reviews the literature; in Section 2 we discuss training subsidies in the Acemoglu and Pischke model of training. Our empirical approach is discussed in Section 3, and Italian training policies are reviewed in Section 4. Section 5 describes the data, Section 6 presents our results and Section 7 includes some robustness exercises. Conclusions follow.

\section{Review of the Literature}

Estimating the effects of work related training on wages is fraught with difficulties. Perhaps the most obvious is that the allocation of training to individuals is not random but subject to choice. The existing empirical literature has addressed this problem using three approaches: a) Heckman style correction for selection into training; b) instrumental variables; c) fixed effects estimates. Good reviews of these approaches include Frazis and Lowenstein, 2006, Leuven and Oosterbeek, 2008, and Bassanini et al, 2007. Parametric selection models need to make potentially restrictive assumptions on the distribution of un-observables. They share with the 
second approach the difficulty of finding credible exclusion restrictions, or variables that affect training participation without directly affecting wages or selection into employment (see Lee, 2005). The last approach removes permanent individual effects from the estimating equation. However, this method effectively eliminates the source of endogeneity in training participation or intensity if this is due to time invariant individual effects. When the wage growth experienced by individuals receiving training is different from that experienced by untrained individuals, fixed effects estimators fail to recover the causal effect of training on wages ${ }^{1}$.

Estimated private returns to workplace training tend to vary substantially in the empirical literature. Relatively low returns are found by Lynch, 1992, who uses the US National Longitudinal Survey of Youth and estimates that one week of training raises (hourly) earnings by 0.2 percent. Similarly, Parent, 1999, finds that one year of training raises earnings by 12 percent. Assuming that one year corresponds to 48 weeks of training, this implies a return for a week of training equal to 0.25 percent. Higher returns are found by Frazis and Lowenstein, 2006, who estimate that a median training spell of 57 hours (about one and a half week of training) yields a wage return of 2.3 percent. Bartel, 1995, uses company data and finds that one day of training increases wages by 2 percent.

Blundell et all, 1996, report that having done one employer provided training course which leads to a higher vocational qualification increases the earnings of British males by close to 15 percent for off - the - job training and by close to 12 percent for on - the - job training. These returns fall to 6.6 and 6.3 percent for training spells that do not lead to a qualification. Booth, 1993, uses British data and finds that one week of training in the first year of the job increases earnings by 1 percent. Veum, 1995, uses the NLSY as done by Lynch, but for a different period of time. His fixed effects estimates imply that one additional hour of training raises (hourly) wages by 0.7 to 0.9 percent. After reviewing this evidence, Leuven and Oosterbeek, 2008, conclude that “.. the literature often finds returns of at least 3\% for a week of private-sector training..” (p.424). In comparison, one year of additional full time education yields a 10 percent return.

\footnotetext{
${ }^{1}$ Pischke, 2001, takes this into account by estimating fixed effects wage growth equations.
} 

$\underline{\text { Model }}$

In this section we introduce training subsidies in the by now standard Acemoglu and Pischke model of investment in general training in imperfectly competitive markets (Acemoglu and Pischke, 1999). A key feature of this model is that firms operating in markets with imperfections may be willing to bear the cost of training even if the imparted skills can be transferred to other firms. This is in line with the empirical evidence (see Bassanini et al, 2007).

Consider a two-period setup. In period 1 the employer trains the employee and pays the training costs ${ }^{2}$. Let the investment in training be denoted by $\tau$. In period 2 the employer and worker either separate or continue their match. In the latter case, they bargain over the wage $w(\tau)$ and production $y=f(\tau)$ occurs. Denote with $v(\tau)$ the worker's outside option. Labour market frictions imply that $f(\tau)>v(\tau)$. The match is affected at the start of period 2 by a negative productivity shock $\varepsilon \approx N\left(0, \sigma^{2}\right)$, and continues if $f(\tau)-w(\tau) \geq \varepsilon$. Letting $\mathrm{G}$ be the distribution function of the shock, the probability of being employed in period 2 is equal to $q=G[f(\tau)-w(\tau)]$.

If the match continues, the wage is bargained between the parties. Assuming Nash bargaining and a zero outside option on the firm side, the outcome of the bargain is

$$
w(\tau)=v(\tau)+\beta[f(\tau)-v(\tau)]
$$

where $\beta$ is the worker's bargaining power. Importantly, the wage does not depend on training costs, because these are bygones at the time of the bargain.

In the first period, the firm decides the investment in training to maximize real profits

\footnotetext{
${ }^{2}$ Training costs are born by employers when workers are credit constrained. Acemoglu and Pischke show that firms are willing to pay these costs even when workers are not credit constrained. The key implications of the model for the purposes of this paper do not change if the training cost is born by the employee.
} 


$$
\pi(\tau)=q(1-\beta)[f(\tau)-v(\tau)]-c(\tau)+s \tau
$$

where $c$ is the training cost function and $s$ is the training subsidy per unit of training. Optimal training $\tau=\tau(s, \beta)$ is increasing in the training subsidy and decreasing in the worker's bargaining power ${ }^{3}$. In the absence of training subsidies, the employer is willing to train and pay the training costs only if there is wage compression $\left(f^{\prime}(0)-v^{\prime}(0)>0\right)$. With training subsidies, training can be funded by the employer even without wage compression.

The model has the following implications for the empirical analysis. First, the training subsidy $s$ affects earnings only by affecting the investment in training. Second, the probability of employment $q$ is affected by training subsidies only because the latter influences training. Third, heterogeneity in the costs and returns to training generate heterogeneous training investments. The model suggests that omitting the training subsidy $s$ from the wage equation in the empirical analysis is a valid exclusion restriction, and that the subsidy itself is a valid instrument for endogenous training.

\section{Our Empirical Approach}

We consider the following empirical model

$$
\begin{aligned}
& \ln w_{i r t}=\kappa_{W}+\gamma_{t}+\gamma_{r}+X_{i r t}{ }^{\prime} \beta_{W}+Q_{r t}{ }^{\prime} \delta_{W}+\theta T_{i r t}+\varepsilon_{i r t} \\
& T_{i r t}=\kappa_{T}+\gamma_{t}+\gamma_{r}+X_{i r t}{ }^{\prime} \beta_{T}+Q_{r t}{ }^{\prime} \delta_{T}+\alpha T S_{r t}+v_{i r t}
\end{aligned}
$$

where $\kappa$ is a constant, $\gamma_{t}$ and $\gamma_{r}$ are time and regional dummies, $\mathrm{X}$ is a vector of individual controls, $\mathrm{Q}$ a vector of region by time variables, $w$ is monthly real wages, $T$ the stock of training, TS the stock of training subsidies (at constant prices), $\varepsilon$ and $v$ are errors, $\operatorname{Cov}\left(\varepsilon_{t}, v_{t}\right) \neq 0$, and the subscripts $i, j$ and $t$ are for the individual, the

\footnotetext{
${ }^{3}$ The first order conditions are $\{q+g(1-\beta)[f(\tau)-v(\tau)]\}(1-\beta)\left[f^{\prime}(\tau)-v^{\prime}(\tau)\right]-c^{\prime}(\tau)+s=0$
} 
region and time respectively. We include in the vector $X$ individual age, age squared, a gender dummy, parental education dummies, education, occupation (white collar jobs) and industry dummies (industry and agriculture dummies), a part time and a firm size dummy (equal to 1 if the employer has less than 100 employees and 0 otherwise).

The standard ordinary least squares estimates of parameter $\theta$, which captures the marginal effect of training on earnings, is likely to be biased for at least two reasons: a) the individual training stock is correlated with unobserved ability; b) there is measurement error in the training stock, which induces attenuation bias. Measurement error can occur if individuals fail to recall short training spells and concentrate their reporting only on longer spells.

In this paper, we address non random allocation to training and measurement error by using instrumental variables. The key exclusion restriction is that the stock of training subsidies does not affect earnings directly, but only via the stock of training. This restriction can be violated in the presence of contextual effects that influence both earnings and training subsidies. This can happen if richer regions have both higher wages and can afford to spend more to subsidize training. We control for region and time specific contextual effects with regional and time dummies. Regional dummies are expected to control also for the quality of training investment, which depend on existing facilities - such as regional training centres and varies slowly over time. The inclusion of these dummies implies that the effect of training incentives $T S$ on the training stock $T$ can be identified only if the former vary both over time and across regions. We document this variation in the next section of the paper.

We include in the empirical specification the (lagged) regional rate of unemployment and the (lagged) regional share of high tech industries. These variables pick up both regional labour market dynamics and variations in the importance of research and development, which is higher in high tech sectors. Omitting these variables may cause the orthogonality condition to fail if region by time variations in the stock of training incentives are correlated with the dynamics of the labour market and the industrial structure. 
Temporary negative shocks that affect wages in a single region can induce regional governments to subsidize training more. To avoid reverse causality (from lower wages to higher incentives), we use the lagged stock of training incentives and rely on the fact that the speed of response of regional governments to temporary shocks is unlikely to be fast.

Since selection into employment (and non-negative wages) is not random, a potential concern is that the regional stock of training incentives affects this selection process directly rather than only indirectly via the training stock. To check for this possibility, we estimate a probit model of employment participation, using the regressors in equation [4] and adding the lagged stock of training incentives, but find no evidence that the latter have a statistically significant effect. Another concern is that the selected instrument is correlated with unobserved ability. This seems unlikely, however, given the time invariant nature of ability and the fact that we are using the region by time variation in training subsidies. Furthermore, our choice of using planned rather than actual training subsidies should guarantee that our instrument is predetermined with respect to the allocation of training funds to firms and employees.

\section{Continuing Vocational Training Policies in Italy}

In Italy, government subsidies to continuing vocational training are managed by regional authorities. Public intervention is organized along three lines: 1) the European Social Fund (ESF); 2) national measures (Laws 236/93 and 53/00) and 3) industry based training funds (ITF), managed by social partners ${ }^{4}$. By and large, these measures are funded by the European Community (Objectives 1 and 3, directives D1 and D2 during the financial period 2000 to 2006 and Objective 4 during the financial period 1994 to 1999) and by a compulsory levy of $0.30 \%$ on national payroll (see the Appendix for further details). We estimate that, during the period 1994-2005, about 3.37 billion euro at constant prices have been allocated by regions to support continuing vocational training and individual training plans, with

\footnotetext{
${ }^{4}$ Since training funds became operational from the second half of 2004 and our sample ends in 2005, we ignore them for the purposes of this paper.
} 
2.7 billion euros funded by the European Social Fund and the rest from the levy on national payroll ${ }^{5}$.

These resources are transferred from the Community and the national government to regional authorities, which allocate them to regional budgets, issue invitations to tender and fund successful applicants. In this paper we use planned expenditures ("impegni") rather than training outlays ("spese”): the former are invitations to tender, the latter are actual expenditures. Plans and outlays can differ in a given fiscal year either because some grants are not awarded or because there are delays between awards and expenditures. In an effort to curb these delays, the European Commission has introduced in 2002 the so called " $n+2$ " rule, which forces regional authorities to spend the allocated resources within 2 years from the award.

Italian regions have substantial discretion and autonomy in the management of training funds. Importantly, there is no explicit rule requiring that the funds received by the national government in a given fiscal year are to be allocated to regional budgets or spent within the same period. While some regions have managed to issue invitations to tender a few months after receiving their funds, other regions have either not been able or have decided not to do so. The Labour Ministry has repeatedly threatened regions which have delayed the budgeting of allocated resources with the withdrawal of funds, but no effective action in this direction has ever been taken (see ISFOL, 2006).

Table 1 shows for each Italian region - with the exclusion of tiny Val d'Aosta and Molise - the cumulated value of planned expenditures per head at 2005 prices and by source of funds ${ }^{6}$. In the first column we consider the European Social Fund and in the second column the resources provided by national laws. There is substantial variation across regions, with Puglia in the South spending the least (about 22.6 euros per head) and Trentino Alto Adige in the North spending the most (about 286.7 euros per head). These differences reflect both the lower employment rate in the South and the lower ability to spend of Southern Italian regions ${ }^{7}$. The

\footnotetext{
${ }^{5}$ Additional training policies during this period include a tax deduction scheme for training expenditures, which operated in 2001 and 2002. This national policy is controlled in our empirical setup by time dummies.

${ }^{6}$ The value per head is obtained by dividing real expenditures by active population in the region.

${ }^{7}$ Since the allocation of resources for training purposes from the national government to regions is based on employment, Southern regions receive less because of their lower employment rate.
} 
North - South divide is not sufficient, however, to account for cross regional differences: for instance, the resources per head allocated to training by Lombardia, the richest region, and Sardinia, a relatively under-developed Southern region, are very similar. Furthermore, there is no evidence that regions which plan to use relatively less the training incentives from national sources compensate by using more intensely the resources received from the European Social Fund. If anything, Table 1 shows that the two sources of funds are complements, not substitutes.

Figure 1 shows how the cumulated value of planned training subsidies per head varies over time across regions, after normalising to 1 the cumulated value in the year 1998. Clearly, there is no common trend. Figure 2 plots the average training stock in region $i$ and period $t$ against the lagged stock of training incentives in the same region and shows that the correlation is positive. Finally, when we decompose the total standard deviation of the cumulated stock of training incentives, we find that the within component (variation over time) is broadly similar in size to the between component (variation across regions). We conclude from this that the selected instrument exhibits useful variation both across regions and over time.

\section{The Data}

We merge the regional data on training subsidies for the years 1998 to 2005 with individual panel data drawn from ILFI. The ILFI panel consists of five waves, with each wave being implemented every two years, starting with 1997 and ending with 2005. In the first wave, the survey collects both current and retrospective information on the relevant events. In the follow-ups, data collection updates the initial information with additional events. The ILFI dataset is particularly well suited for the purpose of this paper because it contains information on (monthly) net earnings, the number of training episodes and several individual characteristics, including education and occupation ${ }^{8}$. Since the first wave in 1997 does not include information on individual earnings, our sample starts from 1999. Additional information on this dataset is provided in the Appendix.

\footnotetext{
${ }^{8}$ An alternative dataset is the Italian section of the European Community Household Panel, which covers the period 1994-2001. A drawback of this survey is that the available information on training includes mainly training incidence and considers only the last training course taken during the past 12 months.
} 
In each wave of the survey, interviewed individuals are asked whether they have received any formal training during the reference period (two years) and the number of training episodes. Training includes any program organized by firms, local authorities and industrial associations that takes place after completion of upper secondary education and is not included in vocational tertiary education ${ }^{9}$.

Even though the survey is every two years, we can construct for each individual annual data on training episodes, using the available information on the year and the month when each episode was started. We allocate to year $t$ all training episodes that start in the year. We use these annual data to compute the training stock with the perpetual inventory method, taking advantage of the fact that in the initial wave of the survey individuals were asked to recall all their training episodes since labour market entry.

To implement this method we need a measure of human capital depreciation. Following Conti, 2005, and Dearden, Reed and Van Reenen, 2006, we use in our baseline estimates a 15 percent depreciation rate, but experiment also with a lower rate ( 5 percent). The depreciation of human capital at the rate $\delta=0.15$ per year implies that the ratio of the estimated impact of a training episode at time $t$ on monthly wages at time $t+n$ to the impact of the same episode on contemporaneous wages is $0.85^{n}$.

In order to avoid having region by year cells with too few observations, we aggregate the original 18 regions into $13^{10}$. In the aggregated regions, the stock of training subsidies is a weighted average of regional data, using active population in each region as weight. We restrict our original sample by: a) including only individuals aged 20 to 55 who are employed in the private sector; b) excluding individuals with missing data on earnings; c) excluding the very few individuals (less than 2 percent of the sample) who have changed region of residence during the sample period.

In the selected sample, the average undiscounted sum of training episodes during the period 1999 to 2005 is 0.933 (with a minimum of zero and maximum of 25

\footnotetext{
${ }^{9}$ We distinguish this type of training from informal training, which is mainly on - the - job.

${ }^{10}$ The remaining regions are: Piemonte, Lombardia, Trentino Alto Adige and Veneto, Friuli Venezia Giulia, Emilia Romagna, Toscana, Liguria, Marche and Umbria, Lazio and Abruzzi, Campania, Puglia, Basilicata and Calabria, Sicilia and Sardegna.
} 
episodes), which increases to 2.269 for the sub-sample who have had at least one training episode since labour market entry (41.14 percent). The discounted sum is lower, at 0.339 and 1.038 respectively. Table 2 shows the undiscounted sum for each of the 13 regions. It turns out that both the sum of training episodes and the percentage of employees receiving any training from labour market entry to 2005 is highest in Friuli Venezia Giulia - a Northern region - and lowest in Campania, a Southern region. Interestingly, the most economically advanced region in the country, Lombardia, lags behind most of the Northern regions in terms both of training episodes and of trained employees. The data about Lombardia may seem puzzling. Notice however that the low training incidence in this region is in line with the information provided by alternative datasets. If we use the European Community Household Panel, for instance, we find that the percentage of workers in the private sector receiving any training during the last year was only 3.9 percent in Lombardia in 2001, compared to 8.9 percent in the North-East, 6.5 percent in Emilia Romagna and 4.6 percent in Lazio ${ }^{11}$.

For each individual in the sample we have information on monthly earnings ${ }^{12}$, years of schooling, occupation, type of contract, firm size and sector of activity. The panel is unbalanced, with 50 percent of individuals present in all waves, 20.7 percent present in three waves and the rest present in one or two waves. The final sample consists of 1928 employees and 4850 observations. Table 3 presents the summary statistics for the key variables in 2005.

\section{The Main Results}

The specification of equation (4) postulates a linear relationship between log earnings and the training stock, measured as the discounted sum of training episodes from labour market entry to current time. Frazis and Lowenstein, 2006, however, argue that a better fitting specification should have the cube root of the training stock rather than the stock itself. With a cube root specification, the marginal returns

\footnotetext{
${ }^{11}$ The relatively low training intensity in Lombardia is also confirmed by the PLUS 2005 survey carried out by ISFOL (the Italian Training Institute).

${ }^{12}$ Unfortunately the number of hours worked in waves later than the first is asked only to respondents who have changed their job.
} 
to training decrease with the invested stock, a plausible assumption. Following their suggestion, our baseline specification has the cube root but we also present results with the linear specification ${ }^{13}$.

Table 4 shows the estimates of the first stage equation (5). The table is organized in four columns: while the former two columns are based on a larger sample which comprises all annual data on training stocks and training incentives and spans the period 1998 to 2005, the remaining two columns are based on the smaller sample with data on earnings, which covers the odd years from 1999 to 2005. In each pair of columns, the former uses the cube root of the training stock as the dependent variable and the latter the training stock.

Since the training stock and the stock of incentives are at different levels of aggregation, we cluster the standard errors by region and year. In all the four columns, we find that the lagged stock of training incentives has a positive and statistically significant effect (at least at the 5 percent level of significance) on the training stock. This effect is very similar in the larger and in the smaller sample. These estimates suggest that one additional (real) euro per head spent in training subsidies increases the discounted training stock by 0.6 percent, a small effect.

If the correlation between the instrument and the endogenous variable is low, the instrument is “weak". To identify weak instruments, Staiger and Stock, 1997, proposed to examine the F-statistic on the inclusion of the instrument in the first stage regression. An F-statistic of less than 10 is indicative of weak instruments. When the instruments are many and weak, the 2SLS estimate of the effect of training on wages is biased toward the probability limit of the corresponding OLS estimate (Angrist and Pischke, 2009). When the model is just-identified, as in our case, 2SLS estimates are median - unbiased but imprecise. Table 4 shows that the F-test is above the threshold value of 10 in the first three columns and below 10 in the last column. Since the 2SLS estimate of the returns to training is based on the smaller sample, these results suggest that we should focus on the specification of equation (4) which uses the cube root of the training stock.

The training stock is higher among the better educated, those working in a white collar job and in larger firms. Somewhat surprisingly, we find that part-timers in the

\footnotetext{
${ }^{13}$ We find that the goodness of fit is marginally higher with the cube root specification.
} 
largest sample are more likely to receive training. This effect, however, is statistically insignificant in the smaller sample. The result is less surprisingly when we realize that the part-timers in our sample are younger and better educated than average. Moreover, they tend to be employed in the service sector.

There is some evidence that an increase in the regional unemployment rate is associated to an increase in the training stock. This counter-cyclical pattern is not new in the literature, see for instance Bassanini and Brunello, 2009. On the other hand, the training stock tends to increase in regions where the percentage of high tech firms rises, although this effect is in most cases imprecisely estimated. This negative relationship might seem surprising. Yet it is consistent with the evidence of lack of complementarity between R\&D and training expenditures (see Ballot, Fakhfakh and Taymaz, 2001, and Bassanini and Brunello, 2009).

Table 5 presents both the random effects and the random effects two stages least squares estimates of the impact of the training stock on log earnings, when the former is instrumented with the lagged stock of training grants. In the table, the first and third columns refer to our baseline specification with the cube root of the training stock, and the remaining columns are based on the log - linear specification. In all specifications there is evidence that the training stock has a positive and statistically significant (at least at the 5 percent level of confidence) effect on log monthly earnings. Evaluated at the sample mean, the marginal effect of one additional current training episode when this is treated as exogenous is 3.2 percent with the cube root specification and 2.1 percent with the linear specification. When the training stock is treated as endogenous, the marginal effect raises to 18.6 percent in the cube root specification and to 14.9 percent in the linear model ${ }^{14}$.

While the ILFI dataset contains information on the number of training days spent in each training episodes, this variable has several missing values and cannot be used meaningfully in a regression analysis. With this drawback in mind, the average duration of a training episode is 21.07 days, which broadly corresponds to four weeks, and the wage return per week ranges from 3.5 to 4.4 percent, depending

\footnotetext{
${ }^{14}$ The estimates show that log earnings are concave in age, higher for males, the better educated and those working as white collars, and lower for part - timers and workers in small firms. There is also evidence that wages decline with regional unemployment and increase with the share of high tech firms in the region.
} 
on the specification. The rather long duration of the training episodes includes in this dataset could be partly responsible of the relatively high returns, as we expect that shorter courses yield lower returns.

The estimated marginal returns to training are high, but broadly in line with the empirical literature. It is important to stress, however, that these returns measure the impact of a current week of training on the current wage. The effect on future wages declines rapidly and is about 20 percent of the impact effect 10 years after the initial investment (see Figure 3). Over a period of 20 years, the average marginal return to an additional week of formal training is $1.35 \%$ at most.

What is the expected wage return of an additional euro allocated to training grants? Since one additional euro in incentives increases the training stock by 0.6 percent, the percentage increase in earnings is 0.11 percent, which corresponds to 15 euro on an annual basis (13 months of pay). Under the null assumption that changes in government subsidies do not affect the decision rules of workers and firms, monthly earnings can be increased by 1 percent if training grants per head rise by about 9 euro.

With heterogeneous returns, the 2SLS estimate does not measure the average treatment effect, but only the local average treatment effect, which corresponds to the return accruing to the individuals in the sample who have changed their training because of variations in the selected instrument (compliers). In general, this effect differs from the average effect both on the treated (those who have positive training stocks) and on the non-treated (those with zero training stocks), and from the average treatment effect. Since the marginal effect of training could vary with observable characteristics, we experiment with interactions of the training stock with gender, age, education and firm size. Only in the last case, however, we find evidence of significantly different effects (at the 10 percent level of confidence).

Table 6 shows our estimates when equations (4) and (5) include interactions of both training and training incentives with a dummy equal to 1 if the firm has less than 100 employees and to 0 otherwise. In either regression, the coefficients of the interacted effects are statistically significant at the 10 percent level of confidence. We find that the elasticity of training to training grants is positive and marginally higher among firms with more than 100 employees. We also find that the marginal 
effect of an additional current training episode is about twice as large for employees of small firms (5.4 percent) than for employees of large firms with at least 100 employees (2.4 percent). As discussed above, this effect declines sharply over time for both types of firm (see Figure 4).

Typically, small firms lack both the resources and the facilities to invest in training and train significantly less than larger firms. Policies that induce firms and workers to invest in additional training are likely to produce higher returns in smaller firms because the marginal benefits to training are decreasing in the quantity of training. An additional factor that could help explain our results is that larger firms have higher bargaining power and can extract higher profits from their training investments than smaller firms, which may be more exposed to the poaching threat, and therefore need to pay higher wage premia to retain their trained employees.

\section{$\underline{\text { 7. Robustness and extensions }}$}

Some of the variables included in vector $X$ of equation (4) are clearly endogenous (education, firm size, occupation, industry, part time). When we estimate the earnings equation by instrumental variables and treat only the training stock TS as endogenous, the failure to account for the endogeneity of other regressors will bias the IV estimate of the effect of $T$ on log earnings if the instrument $T S$ is correlated with the additional endogenous variables (see the Appendix for details). We test whether this is the case by regressing TS on each potential endogenous variable (excluding $T$ ), after partialling out the common set of exogenous variables. Since we cannot reject the null of no correlation at the 5 percent level of confidence for all variables but the firm size dummy, we replicate our estimates in Table 5 by omitting this dummy, with marginal changes on the coefficients of interest ${ }^{15}$.

Our measure of the training stock emphasizes the number of training episodes but overlooks their quality. The time invariant component of quality is picked up by the regional dummies. The residual time varying component, however, could be correlated with training incentives if the availability of funds for training induces

\footnotetext{
${ }^{15}$ The marginal return to training increases slightly in this specification.
} 
employers and employees to substitute quantity for quality. It seems plausible to assume that quality is related to the duration of training courses. We can use the data on training duration available in the dataset to check whether average duration increases or decreases when the stock of training incentives varies. When we do so, we find no evidence of a statistically significant relationship. We conclude from this that, conditional on regional dummies, our inability to control for training quality is unlikely to distort our IV estimates.

It is much more difficult to control for the effects of informal training. Suppose that firms and employees engage both in formal and in informal training. An increase in the availability of training subsidies can induce agents to substitute one type of training for another, for instance to increase formal training - as we find in this paper - and reduce informal training. If this is the case, our IV results underestimate the wage returns to training. If instead agents increase both their formal and their informal training, the estimated effects discussed in this paper over-estimate the true effect. This is an important issue, but one we can do very little about, as informal training is very hard to measure ${ }^{16}$.

We have estimated equation (5) using a linear model in spite of the fact that the dependent variable is either positive or zero. This is not a problem for 2SLS estimates, which remain consistent when the first stage equation is specified as linear even when it is nonlinear (see Angrist and Pischke, 2009). In this section, we verify whether our baseline results are affected when we allow for nonlinearity in the first stage equation. Using the undiscounted training stock, we treat our dependent variable as count data with over-dispersion (variance higher than the mean) and estimate (5) with a negative binomial specification. Next, we compute the fitted values from the first stage and use them as instrument of the undepreciated training stock. As shown in Table 7, we find that the lagged stock of training grants affects positively the training stock, but that the estimated elasticity (0.127) is less than half of that reported in Table 4. We also find that the marginal effect of week of training on current earnings is equal to 3.3 percent, not far from the estimates reported in Table 5.

\footnotetext{
${ }^{16}$ See Pischke, 2007.
} 
Finally, we replicate the 2SLS estimates in Table 5 when the depreciation rate used to compute the training stock is 5 rather than 15 percent. As shown in Figure 3, the impact effect is lower (below 4 percent) but the effect on future earnings declines less sharply and remains above 1 percent 20 years after the original investment.

\section{$\underline{\text { Conclusions }}$}

In this paper we have used an instrumental variables approach to estimate the wage returns to training. The key idea is that regional training policies affect training investments and decisions but have no direct effect on earnings and the probability of employment. Using Italian data, we have found that regional training policies have a statistically significant impact on individual training. The size of this effect, however, is small: one additional euro per head spent in training subsidies in the average Italian region - which corresponds to more than 3 million euro at constant prices - increases the average (discounted) stock of training by a mere 0.6 percent.

The marginal effect of an additional week of training on monthly earnings is instead sizeable and equal to 3.5 to 4.4 percent. However, due to the depreciation of human capital, this effect declines over time. Over a period of 20 years, the average marginal effect is much lower and equal to 1.35 percent. We have shown that these returns - which capture local average treatment effects - are larger in small firms than in large firms. Our interpretation of this result is that small firms and their employees are more likely to be constrained in their training investment decisions by the lack of resources and facilities. Because of this, they usually train less. Therefore, if the marginal benefits of training decline with training intensity, policies that induce individuals and firms to train more are likely to yield higher marginal returns in small than in large firms. 


\section{Appendix}

\section{Funding continuing vocational training in Italy}

In this appendix we describe the funding of continuing vocational training (CVT), or the training which takes place after labour market entry. Vocational education and training are administered in Italy at a regional level under the supervision and guidance of the central government since 1977-78, when the Presidential Decree 616/77 and Law 845/78 were implemented. These laws provide the basic framework for public intervention in the area of vocational training. Resources are funded with $0.30 \%$ of compulsory contributions paid by firms to INPS (National Social Security Institute) as insurance against involuntary unemployment (normally 1.61\% of payroll), and placed into a common fund (The Single Fund for Training, which co-finances the revolving fund for access to the EU Structural Funds), to which Regions have access to finance vocational education and training. We consider the two sources of funds separately.

\section{National funds}

Law 236/93, which contains urgent measures to support employment, established vocational training as a tool of active labour market policy. The law was enacted in 1993 but the first allocation of training resources from the Ministry to regional authorities was in 1997. These resources were devoted mainly to the training of trainers and to company training plans. Eligibility for company plans was restricted to employees in firms which paid insurance against involuntary unemployment. Funds were allocated to co-finance approved projects, and applying firms were supposed to pay at least 20 percent of the total training cost. Each firm could apply for a maximum of 50 million liras.

The procedure to apply and obtain funds can be briefly summarized as follows: each region produces invitations to tender, to which eligible firms could apply. From 1997 to 2001 these invitations were issued simultaneously by regions, and funds were allocated on demand until the end of the fiscal year or until exhaustion of the allocated resources. The distribution of funds to regions was done by the national government, and the key criterion was the number of employees in each region. Applications were evaluated (not in a comparative way) and priority was given to projects which involved the social partners (union and employer associations). Funding was on a first come first served basis.

We distinguish between regional invitations to tender and actual regional expenditures to fund CVT. While the former reflect mainly local political decisions on the allocation of 
resources, the latter are also a function of applications by firms and individuals. In this paper, we use invitations rather than expenditures as a measure of the resources allocated by regions in a given year to fund CVT.

Starting with 1997, the distribution of funds among the 19 Regions and the 2 Autonomous Provinces ${ }^{17}$ was made on an annual basis by the Ministry of Labour Act ("Circolare"), which established the amount and the rules. The initial allocation for company training plans was close to 32 million euros (1997 prices). Act 37/98 in the following year gave to the regions the opportunity of using up to 25 percent of the assigned resources to fund individual rather than company training. This possibility was confirmed also by Act 139/98 (published at the very end of 1998 and thus imputed to 1999 in our database). Act 30/2000 established that all resources not allocated by a region within the next 2 years were to be redistributed among other regions. However, the threatened redistribution never took place. The first panel of Table A1 list the Acts implemented during this period.

The large majority of regions (15) decided to use $25 \%$ of the received funds to finance individual training projects. Each region was free to choose both the selection mechanism and the delivery of funds: some regions introduced a voucher paid directly to training centres; other regions created a catalogue of courses among which applying workers could choose. Following this experience, a new law was enacted in 2000 (Law 53/00), which allowed the systematic funding of individual training plans. As in the case of Law 236, since 2000 the Ministry allocated funds to regions on an annual basis.

At the end of 2000 (imputed to 2001 in our database) a new Act (92/00) was issued to allocate training funds to regions to finance training plans with an industrial or local content ${ }^{18}$. These plans were complex training actions devoted to the promotion of training in a specific geographical area or in a specific sector of economic activity. Social partners played an active role in planning, programming and implementing these actions.

In January 2001 Law 288/00 came into force. With this law, the government established industry based training funds ("fondi paritetici interprofessionali per la formazione continua”). These funds were managed by representatives of employees and firms rather than by regional authorities, with the aim of financing company, sector and regional training plans. They started to deliver subsidies at the end of 2004.

\footnotetext{
${ }^{17}$ The regions are: Valle d'Aosta, Piemonte, Liguria, Lombardia, Veneto, Friuli Venezia Giulia, Emilia Romagna, Toscana , Umbria, Lazio, Marche, Abruzzo, Molise, Puglia, Campania, Basilicata, Calabria, Sicilia e Sardegna.The autonomous provinces are Trento and Bolzano.

${ }^{18}$ A national experiment with these plans took place in 1999 with Act 65/99, which funded 70 projects among 568 applications.
} 
A watershed in the management of regional training funds is 2001, when Constitutional Law 3/01 increased the empowerment of regions, which were assigned exclusive responsibility for vocational education and training. The major novelty in the area of CVT was that the funds allocated by the national government could be used by region with full autonomy in the invitations to tender, which were published in the official regional bulletins. The government explicitly asked regional administrations to favour the integration of each training action with similar actions funded by ESF.

For the purposes of this paper, the greater autonomy enjoyed by regions meant greater heterogeneity in the time lag between allocation of national resources and the issue of invitations to tender. To give an idea of the time used by some regions to open the calls, we report in Table A2 the time lag in days between the national distribution of resources to regions and the regional calls, using data from ISFOL (2005). There is substantial heterogeneity in the ability to spend of Italian regions. For instance, by 2005 many Southern regions had not yet issued the calls for projects funded by the Ministry of Labour in 2003. Our data on planned subsidies are based on ministerial Acts until 2000 and from 2001 on the calls for tenders ${ }^{19}$ published by each region on the official regional bulletin.

\section{The European Social Fund}

In the province of European Structural funds ${ }^{20}$, only the European Social Fund finances continuing vocational training initiatives. According to the Framework Regulations (2052/88), the Structural Funds have the following priority goals:

- Objective 1: structural adjustment of the regions with delayed development. Funds used: ERDF, ESF and the EAGGF-Guidance Section;

- Objective 2: economic reconversion for declining industrial areas. Funds used: ERDF and ESF;

- Objective 3: reduction of long-term unemployment and improvement of professional placement for young people and people excluded from the labour market;

- Objective 4: support to industrial restructuring. Funds used: ESF;

\footnotetext{
${ }^{19}$ This database is available on the web site www.eformazionecontinua.it

${ }^{20}$ The main European Structural funds are: the European Social Fund (ESF), the European Regional Development Fund (ERDF) the European Agricultural Guidance and Guarantee Fund (EAGGF), and the Financial Instrument for Fisheries Guidance (FIFG).
} 
- Objective 5: promotion of rural development. Funds involved: EAGGF, Guidance section, FIFG. Structural adjustment of rural areas. Funds involved: EAGGF, Guidance section, ESF, ERDF.

During the six-year programme from 1994 to 1999, training incentives funded by ESF involved only 14 regions of 20: Piemonte, Valle d'Aosta, Liguria, Lombardy, the autonomous provinces of Bolzano and Trento, Veneto, Fruili Venezia Giulia, EmiliaRomagna, Tuscany, Umbria, Marche, Lazio and Abruzzo (only from 1997). These funds were mobilized under three multi-regional programmes run by the Ministry of Labour (Innovative Actions, Retraining and Requalification of Employees, System Reinforcement). The implementation of training programs funded by the ESF was rather heterogeneous across regions. We collect the data on planned regional expenditures at the regional level during the period 1994-1999 from the publication "Relazione annuale: i rapporti finanziari con l'Unione Europea e l'utilizzazione dei fondi comunitari” by Corte dei Conti, and from ISFOL annual reports.

Turning to the 2000-2006 programming period, the European Social Fund was involved in the support of the European Employment Strategy, which consisted mainly in combating unemployment and developing human resources and social integration. Training incentives for the employed were funded under Directives D1 and D2. A database collecting information on regional training policy funded by the ESF was created at the Ministry of Finance (IGRUE) during this period. Our data on planned training expenditures for this period were kindly provided by ISFOL from the IGRUE database.

\section{The ILFI Dataset}

The ILFI panel consists of five waves, with each wave being implemented in an odd year, starting with 1997 and ending with 2005. In the first wave, the survey collects both current and retrospective information from more than 4000 Italian households. In the follow-ups, interviews update the initial information with additional events and collect all retrospective information for the newly interviewed. The questionnaire is designed to recover individual life histories from birth to the time of the interview, which are organized in episodes. The selected topics include geographical mobility, education and vocational training, work, social origins, and family structure. In the first wave all the significant events in the lives of the interviewed individuals were collected. 
Table A3 shows the number of interviews in each wave. In 1997 households were sampled according to a two-stage stratified procedure. The primary sampling unit was the universe of Italian municipalities in 1996. The final sample consisted of 272 municipalities: the 12 metropolitan municipalities (selected with probability equal to 1) plus a random sample of 260 municipalities extracted with probability proportional to the number of residents from 30 strata defined by region and population size. The secondary sampling unit was the household: within each municipality a random sample of household was extracted and all the individuals in the household older than 18 were interviewed.

The sample is representative of the Italian population at the regional level. A comparison of the main characteristics of this dataset with the 1997 wave of Indagine Multiscopo, a much larger national representative survey carried out by the national statistical institute (ISTAT), was run by Bernardi and Pisati (2003) - see Table A4. They find that the differences between the two surveys are very small. When we compare the 1999 wave of ILFI dataset with the 1998 wave of the Survey on the Income and Wealth of Italian Households by the Bank of Italy, we find that the percentage of individuals aged 20 to 55 and employment was 48.1 in the former dataset and 46.6 in the latter. Furthermore, the average net monthly wage was equal to 1109.2 (standard deviation 548.1) in the Bank of Italy dataset and to 1116.9 euro (standard deviation: 461) in ILFI.

3. Instrumental variables when some explanatory variables are treated as exogenous but are endogenous

Consider the following empirical model

$y=X_{1} \beta_{1}+X_{2} \beta_{2}+u$

where $\operatorname{Cov}\left(X_{1}, u\right) \neq 0$ and $\operatorname{Cov}\left(X_{2}, u\right) \neq 0$. Assume that $\mathrm{Z}$ and $\mathrm{W}$ are the selected instruments. Then the normal equations are

$$
\begin{aligned}
& Z^{\prime} X_{1} \beta_{1}+Z^{\prime} X_{2} \beta_{2}=Z^{\prime} y \\
& W^{\prime} X_{1} \beta_{1}+W^{\prime} X_{2} \beta_{2}=W^{\prime} y
\end{aligned}
$$

From which we get 
$\beta_{1}^{I V}=\frac{\operatorname{Cov}\left(Z^{\prime} y\right)}{\operatorname{Cov}\left(Z^{\prime} X_{1}\right)}-\frac{\operatorname{Cov}\left(Z^{\prime} X_{2}\right)}{\operatorname{Cov}\left(Z^{\prime} X_{1}\right)} \beta_{2}{ }^{I V}$

$\beta_{2}{ }^{I V}=\frac{\operatorname{Cov}\left(W^{\prime} y\right)}{\operatorname{Cov}\left(W^{\prime} X_{2}\right)}-\frac{\operatorname{Cov}\left(W^{\prime} X_{1}\right)}{\operatorname{Cov}\left(W^{\prime} X_{2}\right)} \beta_{1}{ }^{I V}$

Assume now that $X_{2}$ is treated as exogenous, and let $\beta_{2}{ }^{N O}$ be the estimated parameter. Then (A3) becomes

$\beta_{1}^{I V}=\frac{\operatorname{Cov}\left(Z^{\prime} y\right)}{\operatorname{Cov}\left(Z^{\prime} X_{1}\right)}-\frac{\operatorname{Cov}\left(Z^{\prime} X_{2}\right)}{\operatorname{Cov}\left(Z^{\prime} X_{1}\right)} \beta_{2}{ }^{N O}$

$\beta_{2}{ }^{N O}=\frac{\operatorname{Cov}\left(X_{2}^{\prime} y\right)}{\operatorname{Var}\left(X_{2}\right)}-\frac{\operatorname{Cov}\left(X_{2}{ }^{\prime} X_{1}\right)}{\operatorname{Var}\left(X_{2}\right)} \beta_{1}^{I V}$

The first equation in (A4) can be written as

$\beta_{1}^{I V}=\beta_{1}+\frac{\operatorname{Cov}\left(Z^{\prime} X_{2}\right)}{\operatorname{Cov}\left(Z^{\prime} X_{1}\right)}\left(\beta_{2}-\beta_{2}{ }^{N O}\right)$

Since $\beta_{2}{ }^{N O}$ is biased, $\beta_{1}{ }^{I V}$ is also biased if $\operatorname{Cov}\left(Z^{\prime} X_{2}\right) \neq 0$. 


\section{References}

Acemoglu, D. and Pischke, J. 1999, The Structure of Wages and Investment in General Training, Journal of Political Economy, pp. 539-72.

Angrist J and Pischke J, 2009, Almost Harmless Econometrics, Princeton University Press

Ballot, G., F. Fakhfakh and E. Taymaz, 2001, "Firms' human capital, R\&D and performance : A study on French and Swedish firms", Labour Economics 8(4), pp. 443-462.

Bartel, A. 1995, Training, wage growth, and job performance: Evidence from a company database, Journal of Labor Economics, 13, pp. 401-425.

Bassanini A, Booth A, Brunello G, De Paola M and Leuven E, 2007, Workplace Training in Europe, in Brunello G, Garibaldi P and Wasmer E, eds., Education and Training in Europe, Oxford University Press

Bassanini A and Brunello G, 2009, Barriers to Entry, Deregulation and Workplace Training: A Theoretical Model with Evidence from Europe, Cesifo Discussion Paper

Bernardi F. and Pisati M. (2003) Il disegno della ricerca in Vite ineguali ed. by Schizzerotto A. Il Mulino

Blundell R, Dearden L and Meghir C, 1996, The Determinants and Effects of Work Related Training in Britain, IFS, London

Booth A, 1993, Private Sector Training and Graduate Earnings, Review of Economics and Statistics, 76, 164-70

Cameron C. and Trivedi P., 2009 Microeconometrics Using Stata, Stata Press books, StataCorp LP

Conti G, 2005, "Training, productivity and wages in Italy", Labour Economics, 12(4), August 2005, 557-576

Corte dei Conti (1999) Financial relationship with U.E. and use of Community Funds. Annual Report.

Dearden, L., Reed H. and Van Reenen J., 2000, Who gains when workers train? Training and corporate productivity in a panel of British industries, Centre for Economic Policy Research Discussion, Paper No. 2486

Frazis L and Lowenstein M, 2006, On the Job Training, Now, The Essence of Knowledge, Boston

ISFOL (2006) La formazione continua in Italia. Rapporto 2006, ISFOL Roma.

ISFOL (2005) La formazione continua in Italia. Rapporto 2005, ISFOL Roma.

Lee D, 2005, Training, Wages, and Sample Selection: Estimating Sharp Bounds on Treatment Effects, NBER Working Paper 11721

Leuven E and Oosterbeek H, 2008, An alternative approach to estimate the wage returns to private-sector training, Journal of Applied Econometrics, vol. 23(4), pages 423-434.

Lynch, L. (1992), Private Sector Training and the Earnings of Young Workers, American Economic Review, vol. 82, pp. 299-312.

Parent, D. (1999), Wages and mobility: The impact of employer-provided training, Journal of Labor Economics, 17(2), pp. 298-317 
Pischke, J. (2001), Continuous training in Germany, Journal of Population

Economics, 14:523548.

Pischke, J. 2007, Comments to Bassanini et al, in Brunello G, Garibaldi, P and Wasmer E, 2007, Education and Training in Europe, Oxford University Press

Veum, J. (1995), Sources of training and their impact on wages, Industrial and Labor Relations Review, 48 (4), pp. 812-26. 
$\underline{\text { Tables and Figures }}$

Table 1. Regional Planned Training Expenditures. Cumulated stock 1994-2005. Real Euros per Head.

\begin{tabular}{l|cc}
\hline & ESF & 236 and 53 \\
\hline & 100.74 & 23.10 \\
Piemonte & 64.98 & 15.58 \\
Lombardia & 251.36 & 35.43 \\
Trentino Alto Adige & 94.77 & 21.06 \\
Veneto & 144.33 & 32.88 \\
Friuli Venezia Giulia & 153.32 & 31.47 \\
Emilia Romagna & 89.51 & 19.96 \\
Liguria & 71.60 & 15.75 \\
Toscana & 62.66 & 16.82 \\
Marche & 104.14 & 23.52 \\
Umbria & 61.48 & 16.63 \\
Lazio & 68.96 & 19.86 \\
Abruzzi & 26.00 & 12.97 \\
Campania & 10.69 & 11.91 \\
Puglia & 42.27 & 30.68 \\
Basilicata & 18.12 & 7.36 \\
Calabria & 34.86 & 5.10 \\
Sicilia & 69.27 & 15.74 \\
Sardegna & & \\
\hline
\end{tabular}

Source: see the Appendix 
Table 2. Sum of Training Episodes and Percentage of Workers receiving any Training. By region. Year: 2005

\begin{tabular}{l|ccc}
\hline & $\begin{array}{c}\text { Sum of } \\
\text { training } \\
\text { episodes }\end{array}$ & $\begin{array}{c}\% \text { of } \\
\text { trained } \\
\text { workers }\end{array}$ & $\begin{array}{c}\text { Sum of training } \\
\text { episodes for } \\
\text { trained workers }\end{array}$ \\
\hline Piemonte & 1.071 & 0.442 & 2.419 \\
Lombardia & 0.725 & 0.355 & 2.042 \\
Trentino Alto Adige and Veneto & 1.362 & 0.514 & 2.647 \\
Friuli Venezia Giulia & 2.111 & 0.722 & 2.923 \\
Emilia Romagna & 0.704 & 0.422 & 1.666 \\
Liguria & 0.653 & 0.307 & 2.125 \\
Toscana & 1.209 & 0.493 & 2.450 \\
Marche and Umbria & 0.958 & 0.375 & 2.555 \\
Lazio and Abruzzi & 0.982 & 0.377 & 2.604 \\
Campania & 0.271 & 0.171 & 1.583 \\
Puglia & 0.807 & 0.384 & 2.100 \\
Basilicata and Calabria & 1.057 & 0.228 & 4.625 \\
Sicilia and Sardegna & 0.557 & 0.285 & 1.950 \\
\hline & & & \\
\hline
\end{tabular}

Source: see the Appendix 
Table 3. Summary Statistics

\begin{tabular}{l|cc}
\hline & Mean & $\begin{array}{c}\text { Standard } \\
\text { deviation }\end{array}$ \\
\hline Monthly earnings & 1093.90 & 451.97 \\
Training stock (discount rate: 15 percent) & 0.34 & 0.87 \\
Age & 37.56 & 9.30 \\
Gender (male=1) & 0.61 & - \\
Year of Schooling & 10.43 & 3.47 \\
White collar job & 0.37 & - \\
Part timer & 0.10 & - \\
Regional lagged unemployment rate & 8.74 & 6.62 \\
Regional share of high tech industries & 3.92 & 1.09 \\
Percentage of firms with less than 100 employees & 69.67 & - \\
Parental background: at least one parent with upper sec & 0.37 & - \\
education or more & & \\
Number of observations & 4850 & \\
Number of individuals & 1928 & \\
\hline & & \\
\hline
\end{tabular}


Table 4. First stage estimates - full sample and subsample with positive earnings. Private sector employees only. Dependent variable: cubic root of the training stock and training stock T. 13 regions.

\begin{tabular}{|c|c|c|c|c|}
\hline & $\begin{array}{c}\text { (1) } \\
\text { Full sample } \\
\text { Cube root of T } \\
1998-2005\end{array}$ & $\begin{array}{c}(2) \\
\text { Full sample } \\
\text { Linear T } \\
1998-2005\end{array}$ & $\begin{array}{c}(3) \\
\text { Subsample } \\
\text { with wage }>0 \\
\text { Cube root of } \\
\text { T } \\
1999,2001 \text {, } \\
2003,2005\end{array}$ & $\begin{array}{c}(4) \\
\text { Subsample with } \\
\text { wage }>0 \\
\text { Linear T } \\
\text { 1999,2001,2003, } \\
\text { 2005 }\end{array}$ \\
\hline Age & $\begin{array}{c}0.011 * * * \\
{[0.003]}\end{array}$ & $\begin{array}{c}0.018^{* * *} \\
{[0.006]}\end{array}$ & $\begin{array}{c}0.022 * * * \\
{[0.005]}\end{array}$ & $\begin{array}{c}0.033^{* * *} \\
{[0.009]}\end{array}$ \\
\hline Age squared & $\begin{array}{c}-0.000 * * * \\
{[0.000]}\end{array}$ & $\begin{array}{c}-0.000 * * * \\
{[0.000]}\end{array}$ & $\begin{array}{c}-0.000 * * * \\
{[0.000]}\end{array}$ & $\begin{array}{c}-0.000 * * * \\
{[0.000]}\end{array}$ \\
\hline Gender & $\begin{array}{c}0.003 \\
{[0.010]}\end{array}$ & $\begin{array}{l}0.030^{*} \\
{[0.015]}\end{array}$ & $\begin{array}{c}0.002 \\
{[0.013]}\end{array}$ & $\begin{array}{c}0.033 \\
{[0.024]}\end{array}$ \\
\hline Lagged incentives stock $* 100$ & $\begin{array}{c}0.155^{* * *} \\
{[0.025]}\end{array}$ & $\begin{array}{c}0.274 * * * \\
{[0.065]}\end{array}$ & $\begin{array}{c}0.156 * * * \\
{[0.047]}\end{array}$ & $\begin{array}{l}0.273^{* *} \\
{[0.102]}\end{array}$ \\
\hline $\begin{array}{l}\text { Regional unemployment rate } \\
\text { (lagged) } \\
\text { \% firms in high tech industries } \\
\text { (lagged) }\end{array}$ & $\begin{array}{c}0.000 \\
{[0.001]} \\
-0.031^{* * *} \\
{[0.009]}\end{array}$ & $\begin{array}{c}0.006^{*} \\
{[0.003]} \\
-0.013 \\
{[0.019]}\end{array}$ & $\begin{array}{c}0.002 \\
{[0.002]} \\
-0.021 \\
{[0.014]}\end{array}$ & $\begin{array}{c}0.010^{* *} \\
{[0.005]} \\
0.006 \\
{[0.029]}\end{array}$ \\
\hline Education: ISCED $<3$ & $\begin{array}{c}0.053^{* * * *} \\
{[0.009]}\end{array}$ & $\begin{array}{c}0.052^{* * *} \\
{[0.016]}\end{array}$ & $\begin{array}{c}0.055^{* * * *} \\
{[0.013]}\end{array}$ & $\begin{array}{l}0.063^{* *} \\
{[0.025]}\end{array}$ \\
\hline Education: ISCED=3 & $\begin{array}{c}0.145^{* * *} \\
{[0.011]}\end{array}$ & $\begin{array}{c}0.224^{* * *} \\
{[0.023]}\end{array}$ & $\begin{array}{c}0.156^{* * *} \\
{[0.018]}\end{array}$ & $\begin{array}{c}0.260 * * * \\
{[0.040]}\end{array}$ \\
\hline Education: ISCED>3 & $\begin{array}{c}0.256 * * * \\
{[0.022]}\end{array}$ & $\begin{array}{c}0.496 * * * \\
{[0.054]}\end{array}$ & $\begin{array}{c}0.263 * * * \\
{[0.035]}\end{array}$ & $\begin{array}{c}0.524 * * * \\
{[0.080]}\end{array}$ \\
\hline White collar job & $\begin{array}{c}0.101^{* * *} \\
{[0.007]}\end{array}$ & $\begin{array}{c}0.088 * * * \\
{[0.015]}\end{array}$ & $\begin{array}{c}0.111^{* * *} \\
{[0.012]}\end{array}$ & $\begin{array}{c}0.092 * * * \\
{[0.025]}\end{array}$ \\
\hline Part time job & $\begin{array}{l}0.039^{* *} \\
{[0.018]}\end{array}$ & $\begin{array}{l}0.059^{*} \\
{[0.035]}\end{array}$ & $\begin{array}{c}0.022 \\
{[0.028]}\end{array}$ & $\begin{array}{c}0.059 \\
{[0.059]}\end{array}$ \\
\hline $\begin{array}{l}\text { Firm with less than } 100 \\
\text { employees }\end{array}$ & $\begin{array}{c}-0.158^{* * *} \\
{[0.013]}\end{array}$ & $\begin{array}{c}-0.228 * * * \\
{[0.028]}\end{array}$ & $\begin{array}{c}-0.177^{* * *} \\
{[0.017]}\end{array}$ & $\begin{array}{c}-0.268 * * * \\
{[0.040]}\end{array}$ \\
\hline $\begin{array}{l}\text { F-test } \\
\text { Elasticity }\end{array}$ & $\begin{array}{l}36.69 \\
0.338\end{array}$ & $\begin{array}{l}17.57 \\
0.314\end{array}$ & $\begin{array}{l}10.87 \\
0.369\end{array}$ & $\begin{array}{l}7.05 \\
0.339\end{array}$ \\
\hline $\begin{array}{l}\text { Observations } \\
\text { R-squared }\end{array}$ & $\begin{array}{l}11495 \\
0.171\end{array}$ & $\begin{array}{l}11495 \\
0.117 \\
\end{array}$ & $\begin{array}{l}4850 \\
0.185\end{array}$ & $\begin{array}{l}4850 \\
0.125 \\
\end{array}$ \\
\hline
\end{tabular}

Note: Clustered standard errors in brackets; ${ }^{* * *} p<0.01,{ }^{* *} p<0.05,{ }^{*} p<0.1$. Each regression includes a constant, regional, year and industry dummies, two parental education dummies and a dummy equal to 1 if firm size is missing. 
Table 5. Ordinary least squares and IV estimates. Dependent variable: log monthly real earnings. 13 regions. Years 1999, 2001, 2003 and 2005

\begin{tabular}{|c|c|c|c|c|}
\hline & $\begin{array}{c}(1) \\
\text { Random } \\
\text { effects }\end{array}$ & $\begin{array}{c}(2) \\
\text { Random } \\
\text { effects }\end{array}$ & $\begin{array}{c}\text { (3) } \\
\text { RE-IV }\end{array}$ & $\begin{array}{c}(4) \\
\text { RE-IV }\end{array}$ \\
\hline Age & $\begin{array}{c}0.036 * * * \\
{[0.005]}\end{array}$ & $\begin{array}{c}0.036 * * * \\
{[0.005]}\end{array}$ & $\begin{array}{c}0.032 * * * \\
{[0.006]}\end{array}$ & $\begin{array}{c}0.035^{* * *} \\
{[0.005]}\end{array}$ \\
\hline Age squared & $\begin{array}{c}-0.000^{* * *} \\
{[0.000]}\end{array}$ & $\begin{array}{c}-0.000^{* * *} \\
{[0.000]}\end{array}$ & $\begin{array}{c}-0.000^{* * *} \\
{[0.000]}\end{array}$ & $\begin{array}{c}-0.000^{* * *} \\
{[0.000]}\end{array}$ \\
\hline Gender & $\begin{array}{c}0.256^{* * *} \\
{[0.015]}\end{array}$ & $\begin{array}{c}0.255^{* * *} \\
{[0.015]}\end{array}$ & $\begin{array}{c}0.255^{* * *} \\
{[0.029]}\end{array}$ & $\begin{array}{c}0.254^{* * *} \\
{[0.020]}\end{array}$ \\
\hline Training Stock (Cube Root) & $\begin{array}{c}0.047 * * * \\
{[0.012]}\end{array}$ & & $\begin{array}{l}0.273 * * \\
{[0.123]}\end{array}$ & \\
\hline Training Stock & & $\begin{array}{c}0.021^{* * *} \\
{[0.006]}\end{array}$ & & $\begin{array}{l}0.149 * * \\
{[0.060]}\end{array}$ \\
\hline $\begin{array}{l}\text { Regional unemployment rate } \\
\text { (lagged) }\end{array}$ & $\begin{array}{c}-0.006 * * * \\
{[0.009]}\end{array}$ & $\begin{array}{c}-0.006 * * * \\
{[0.009]}\end{array}$ & $\begin{array}{c}-0.005^{* *} \\
{[0.009]}\end{array}$ & $\begin{array}{c}-0.007 * * * \\
{[0.009]}\end{array}$ \\
\hline $\begin{array}{l}\text { \% of high tech industries } \\
\text { (lagged) }\end{array}$ & $\begin{array}{c}0.037 * * * \\
{[0.009]}\end{array}$ & $\begin{array}{c}0.037 * * * \\
{[0.009]}\end{array}$ & $\begin{array}{c}0.023 * * * \\
{[0.009]}\end{array}$ & $\begin{array}{c}0.027 * * * \\
{[0.009]}\end{array}$ \\
\hline Education: ISCED $<3$ & $\begin{array}{c}0.091^{* * *} \\
{[0.026]}\end{array}$ & $\begin{array}{c}0.093 * * * \\
{[0.025]}\end{array}$ & $\begin{array}{c}0.074 \\
{[0.050]}\end{array}$ & $\begin{array}{c}0.081^{* *} \\
{[0.035]}\end{array}$ \\
\hline Education: ISCED=3 & $\begin{array}{c}0.153 * * * \\
{[0.029]}\end{array}$ & $\begin{array}{c}0.155^{* * *} \\
{[0.028]}\end{array}$ & $\begin{array}{l}0.133^{* *} \\
{[0.060]}\end{array}$ & $\begin{array}{c}0.128 * * * \\
{[0.042]}\end{array}$ \\
\hline Education: ISCED>3 & $\begin{array}{c}0.389 * * * \\
{[0.040]}\end{array}$ & $\begin{array}{c}0.390 * * * \\
{[0.040]}\end{array}$ & $\begin{array}{c}0.357 * * * \\
{[0.085]}\end{array}$ & $\begin{array}{c}0.336 * * * \\
{[0.063]}\end{array}$ \\
\hline White collar job & $\begin{array}{c}0.110^{* * *} \\
{[0.017]}\end{array}$ & $\begin{array}{c}0.113^{* * *} \\
{[0.017]}\end{array}$ & $\begin{array}{l}0.053 * * \\
{[0.027]}\end{array}$ & $\begin{array}{c}0.086 * * * \\
{[0.022]}\end{array}$ \\
\hline Part - time job & $\begin{array}{c}-0.384 * * * \\
{[0.020]}\end{array}$ & $\begin{array}{c}-0.384 * * * \\
{[0.020]}\end{array}$ & $\begin{array}{c}-0.364 * * * \\
{[0.027]}\end{array}$ & $\begin{array}{c}-0.377 * * * \\
{[0.024]}\end{array}$ \\
\hline $\begin{array}{l}\text { Firm with less than } 100 \\
\text { employees }\end{array}$ & $\begin{array}{c}-0.077^{* * *} \\
{[0.016]}\end{array}$ & $\begin{array}{c}-0.079 * * * \\
{[0.016]}\end{array}$ & $\begin{array}{l}-0.047 \\
{[0.029]}\end{array}$ & $\begin{array}{c}-0.053^{* *} \\
{[0.023]}\end{array}$ \\
\hline $\begin{array}{l}\text { Marginal effect of a current } \\
\text { training episode }\end{array}$ & 0.032 & 0.021 & 0.186 & 0.149 \\
\hline $\begin{array}{l}\text { Marginal effect of a current } \\
\text { week of training }\end{array}$ & 0.007 & 0.005 & 0.044 & 0.035 \\
\hline Elasticity & 0.010 & 0.007 & 0.063 & 0.050 \\
\hline Observations & 4850 & 4850 & 4850 & 4850 \\
\hline
\end{tabular}


Table 6. Effect of incentives on training and IV estimates of the effect of the cube root of training on log wages. With interactions with firm size. 13 regions.

\begin{tabular}{|c|c|c|}
\hline & $\begin{array}{c}(1) \\
\text { First stage }\end{array}$ & $\begin{array}{c}(2) \\
\text { RE-IV }\end{array}$ \\
\hline Lagged incentives stock x 100 & $\begin{array}{c}0.168 * * * \\
{[0.017]}\end{array}$ & \\
\hline $\begin{array}{l}\text { Lagged incentive stock } x \\
\text { Firm size }>100 \text { dummy x } 100\end{array}$ & $\begin{array}{l}0.033 * * * \\
{[0.012]}\end{array}$ & \\
\hline Lagged Training Stock & & $\begin{array}{l}0.287 * * \\
{[0.125]}\end{array}$ \\
\hline $\begin{array}{l}\text { Lagged Training Stock x } \\
\text { Firm Size }>100 \text { Dummy }\end{array}$ & & $\begin{array}{l}-0.114^{*} \\
{[0.066]}\end{array}$ \\
\hline $\begin{array}{l}\text { Elasticity firms with less } \\
\text { than } 100 \text { employees }\end{array}$ & 0.401 & \\
\hline $\begin{array}{l}\text { Elasticity firms with more } \\
\text { than } 100 \text { employees }\end{array}$ & 0.410 & \\
\hline $\begin{array}{l}\text { Marginal effect firms with } \\
\text { less than } 100 \text { employees }\end{array}$ & & 0.219 \\
\hline $\begin{array}{l}\text { Marginal effect firms with } \\
100 \text { or more employees }\end{array}$ & & 0.109 \\
\hline Observations & 11495 & 4850 \\
\hline
\end{tabular}


Table 7. Estimates of equation (5) using a negative binomial and of equation (4) by IV. Training variable: net training stock. 13 regions.

\begin{tabular}{|c|c|c|}
\hline & $\begin{array}{l}(1) \\
\text { Net training } \\
\text { stock }\end{array}$ & $\begin{array}{c}(2) \\
\text { Log earnings; } \\
\text { RE-IV }\end{array}$ \\
\hline Age & $\begin{array}{c}0.099 * * * \\
{[0.015]}\end{array}$ & $\begin{array}{c}0.028 * * * \\
{[0.006]}\end{array}$ \\
\hline Age squared & $\begin{array}{c}-0.001^{* * *} \\
{[0.000]}\end{array}$ & $\begin{array}{c}-0.000 * * * \\
{[0.000]}\end{array}$ \\
\hline Gender & $\begin{array}{c}0.011 \\
{[0.045]}\end{array}$ & $\begin{array}{c}0.257 * * * \\
{[0.018]}\end{array}$ \\
\hline Lagged incentives stock $* 100$ & $\begin{array}{c}0.258 * * * \\
{[0.084]}\end{array}$ & \\
\hline Net training stock & & $\begin{array}{l}0.142^{* *} \\
{[0.060]}\end{array}$ \\
\hline Regional unemployment rate (lagged) & $\begin{array}{c}-0.010^{* *} \\
{[0.004]}\end{array}$ & $\begin{array}{c}-0.008^{* * *} \\
{[0.002]}\end{array}$ \\
\hline \% firms in high tech industries (lagged) & $\begin{array}{c}-0.094 * * * \\
{[0.032]}\end{array}$ & $\begin{array}{c}0.026^{* * *} \\
{[0.010]}\end{array}$ \\
\hline Education: ISCED $<3$ & $\begin{array}{c}0.612 * * * \\
{[0.093]}\end{array}$ & $\begin{array}{c}0.056 \\
{[0.035]}\end{array}$ \\
\hline Education: ISCED=3 & $\begin{array}{c}0.884 * * * \\
{[0.085]}\end{array}$ & $\begin{array}{l}0.097 * * \\
{[0.045]}\end{array}$ \\
\hline Education: ISCED>3 & $\begin{array}{c}1.029 * * * \\
{[0.128]}\end{array}$ & $\begin{array}{c}0.298 * * * \\
{[0.067]}\end{array}$ \\
\hline White collar job & $\begin{array}{c}0.312^{* * *} \\
{[0.028]}\end{array}$ & $\begin{array}{c}0.087^{* * *} \\
{[0.022]}\end{array}$ \\
\hline Part time job & $\begin{array}{l}0.166^{* *} \\
{[0.069]}\end{array}$ & $\begin{array}{c}-0.386^{* * * *} \\
{[0.024]}\end{array}$ \\
\hline Firm with less than 100 employees & $\begin{array}{c}-0.541^{* * * *} \\
{[0.043]}\end{array}$ & $\begin{array}{c}-0.026 \\
{[0.031]}\end{array}$ \\
\hline $\begin{array}{l}\text { Elasticity } \\
\text { Marginal effect }\end{array}$ & 0.127 & 0.142 \\
\hline Observations & 11495 & 4850 \\
\hline
\end{tabular}

Note. Column 1: clustered robust standard errors in brackets; column 2: standard errors in brackets; $* * *$ $\mathrm{p}<0.01,{ }^{* *} \mathrm{p}<0.05, * \mathrm{p}<0.1$. Each regression includes a constant, regional, year and industry dummies, two parental education dummies and a dummy equal to 1 if firm size is missing. 
Table A1: distribution of funds based on national resources. Laws 236 /93 and 53/00

\begin{tabular}{|c|c|c|c|c|}
\hline & \multicolumn{2}{|c|}{ Law 236/93 } & \multicolumn{2}{|c|}{ Law 53/00 } \\
\hline Year & $\begin{array}{l}\text { Act } \\
\text { First perio }\end{array}$ & $\begin{array}{l}\text { Resou } \\
\text { entral }\end{array}$ & $\begin{array}{l}\text { Act } \\
\text { istration }\end{array}$ & Resources \\
\hline 1997 & $174 / 97$ & 32 & - & - \\
\hline \multirow[t]{2}{*}{1998} & $37 / 98$ & 65 & - & - \\
\hline & 139/98 & 102 & - & - \\
\hline 1999 & $51 / 99$ & 85 & - & - \\
\hline \multirow[t]{3}{*}{2000} & $30 / 2000$ & 77 & - & - \\
\hline & $92 / 00 * *$ & 153 & - & - \\
\hline & \multicolumn{4}{|c|}{ Second Period: regional autonomy } \\
\hline 2001 & $511 / 2001$ & 92.9 & $167 / 01$ & 30.9 \\
\hline 2002 & - & - & - & - \\
\hline 2003 & $296 / 03$ & 50 & - & - \\
\hline \multirow[t]{2}{*}{2004} & $243 / 04$ & 62.8 & $136 / 04$ & 30.9 \\
\hline & - & - & $349 / 04$ & 15.5 \\
\hline 2005 & - & - & - & - \\
\hline
\end{tabular}

Notes: the data are in million euro. ** issued on 29/12/2000 and thus imputed to 2001. 
Table A2. Number of day between the national distribution of resource and the regional call for tenders (when issued)

\begin{tabular}{|c|c|c|}
\hline & $296 / 03$ & $243 / 04$ \\
\hline Piemonte & 73 & - \\
\hline Liguria & 88 & 92 \\
\hline Lombardia & 250 & - \\
\hline Bolzano & * & 230 \\
\hline Trento & 17 & - \\
\hline Veneto & 105 & 75 \\
\hline Friuli V G & 133 & 247 \\
\hline Emilia Romagna & 118 & 144 \\
\hline Toscana & 351 & - \\
\hline Umbria & 349 & 5 \\
\hline Marche & 259 & 159 \\
\hline Lazio & 484 & 140 \\
\hline Abruzzo & 467 & 123 \\
\hline Molise & 115 & 56 \\
\hline Campania & 407 & 133 \\
\hline Puglia & - & - \\
\hline Basilicata & - & - \\
\hline Calabria & - & - \\
\hline Sicilia & - & - \\
\hline Sardegna & 262 & - \\
\hline Valle D’Aosta & - & - \\
\hline Average number of days & 232 & 128 \\
\hline
\end{tabular}

*the resources were not used to finance CVT. 
Table A3. ILFI number of interviews by waves

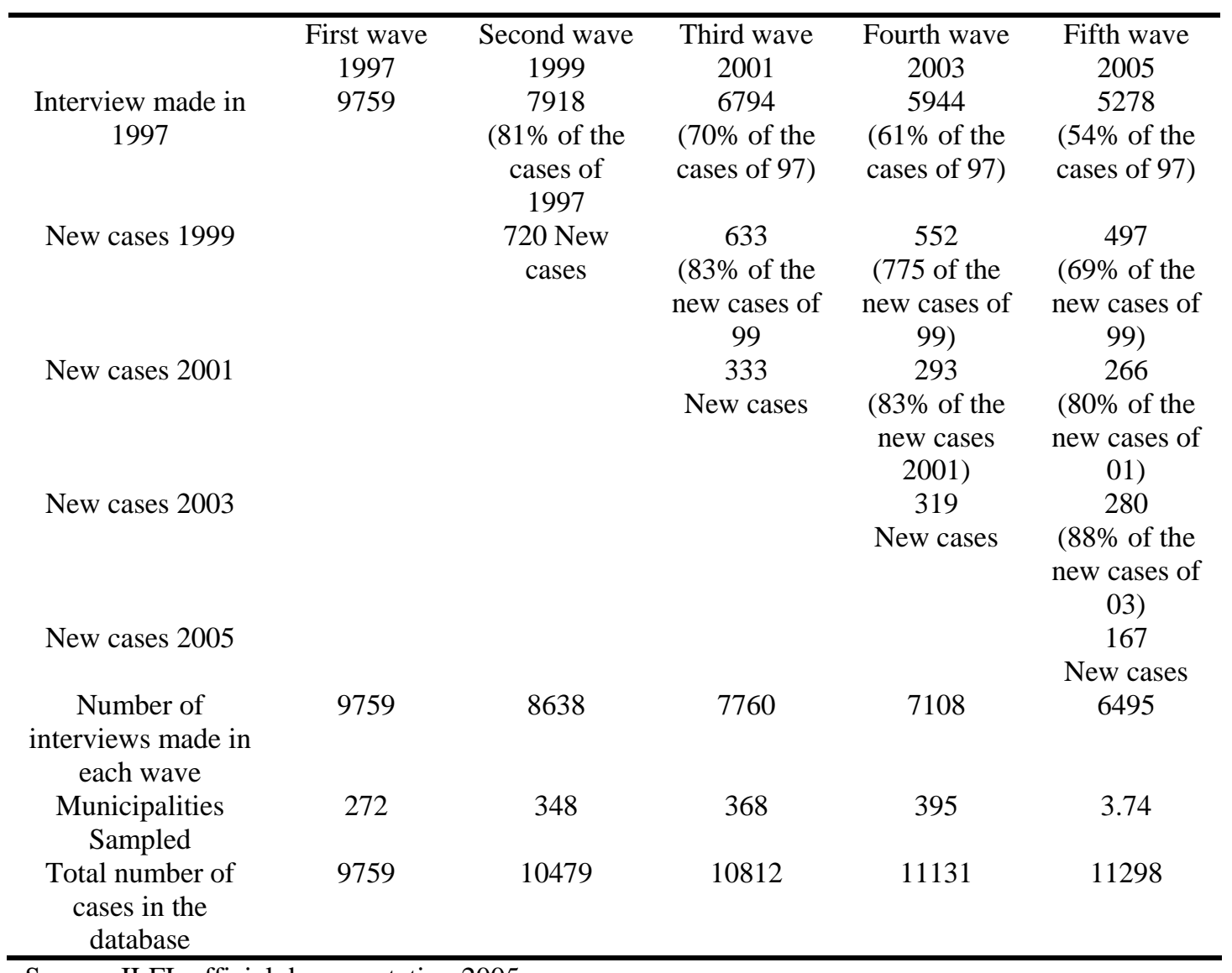

Source: ILFI, official documentation 2005 
Table A4. Comparison between ILFI and Indagine Multiscopo (1997)

\begin{tabular}{|c|c|c|}
\hline Vustili & IIFI $10 \%$ & $\begin{array}{l}\text { M-linsp: } \\
\text { lisul } 157\end{array}$ \\
\hline \multicolumn{3}{|l|}{ 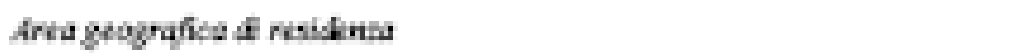 } \\
\hline Modroneil & $z y$ & 2,0 \\
\hline Mod-Esi & 13,4 & 189 \\
\hline Cnes & 197 & 196 \\
\hline But & $\mathrm{n}, \mathrm{z}$ & 23 \\
\hline Inste & 11.4 & 01,3 \\
\hline \multicolumn{3}{|l|}{ Exs } \\
\hline Deani & 474 & 48,0 \\
\hline Dwate & 52,8 & 520 \\
\hline \multicolumn{3}{|l|}{ Clowe of ald } \\
\hline 182 & 5,1 & 206 \\
\hline $30-30$ & 192 & 194 \\
\hline$+\pi-3$ & 13,6 & 159 \\
\hline$\$ 45$ & 17,0 & 154 \\
\hline 6-0 & 127 & -40 \\
\hline$\pi \rightarrow$ & 3,7 & 96 \\
\hline $30+$ & 3,2 & 41 \\
\hline \multicolumn{3}{|l|}{ Tiso at nuste } \\
\hline 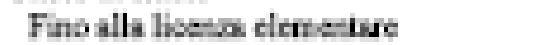 & 31,5 & 324 \\
\hline Iibens nolik & 23,4 & 281 \\
\hline Diplan di quilifea poltsibale & 4,7 & 57 \\
\hline Diplond dinkils & 7,3 & $2 \mathrm{mi} 0$ \\
\hline Diplan Enevisiatie & 09 & 98 \\
\hline laura & 70 & 59 \\
\hline \multicolumn{3}{|l|}{ 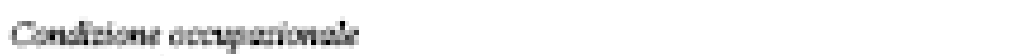 } \\
\hline berswi & $47 \varepsilon$ & 42 \\
\hline Dawsupiok & 3,7 & 26 \\
\hline 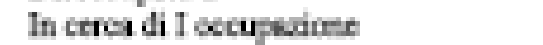 & 2,5 & 33 \\
\hline Cusiling & 13. & 77,6 \\
\hline Pulinks & 13,9 & 29 \\
\hline Bulkmbobs & 66 & 58 \\
\hline Alto & 3,0 & 3,6 \\
\hline \multicolumn{3}{|l|}{ 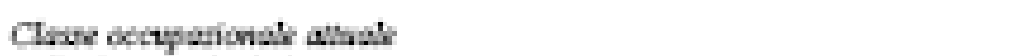 } \\
\hline 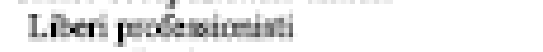 & $4 !$ & 46 \\
\hline Inpentike & 2,5 & 32 \\
\hline Powla boghena urtese & $17 \%$ & 266 \\
\hline 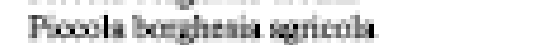 & $2 !$ & 28 \\
\hline Driumi & 57 & 72 \\
\hline Inplejil & 3,2 & 343 \\
\hline 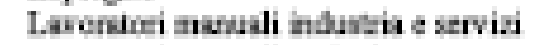 & 39,5 & 2,3 \\
\hline 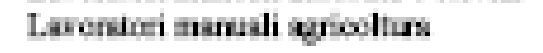 & 2,7 & 21 \\
\hline \multicolumn{3}{|l|}{ Boretwit } \\
\hline Chibetile & $x_{4} 4$ & 257 \\
\hline Colmaloh & 6i! & 615 \\
\hline spanks & 0 & 1,3 \\
\hline Dworbuh & 1,2 & 1,2 \\
\hline Volimok & 10 & 1,1 \\
\hline
\end{tabular}


Figure 1. Stock of Regional Training Grants per Head. Years 1998-2005. Normalized to 1 in 1998.
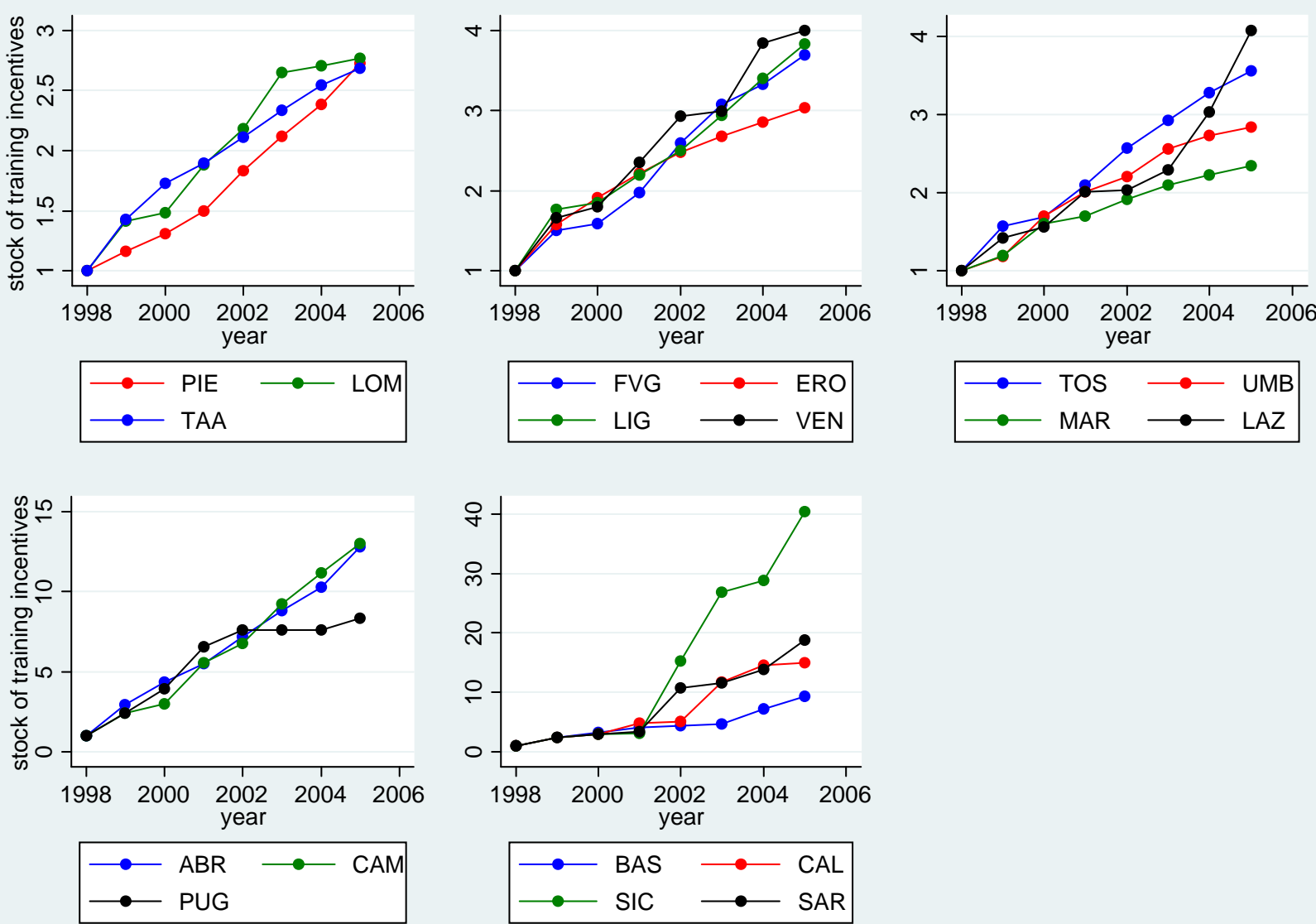
Figure 2. Training stock (discounted number of episodes) and training grants. By year and region

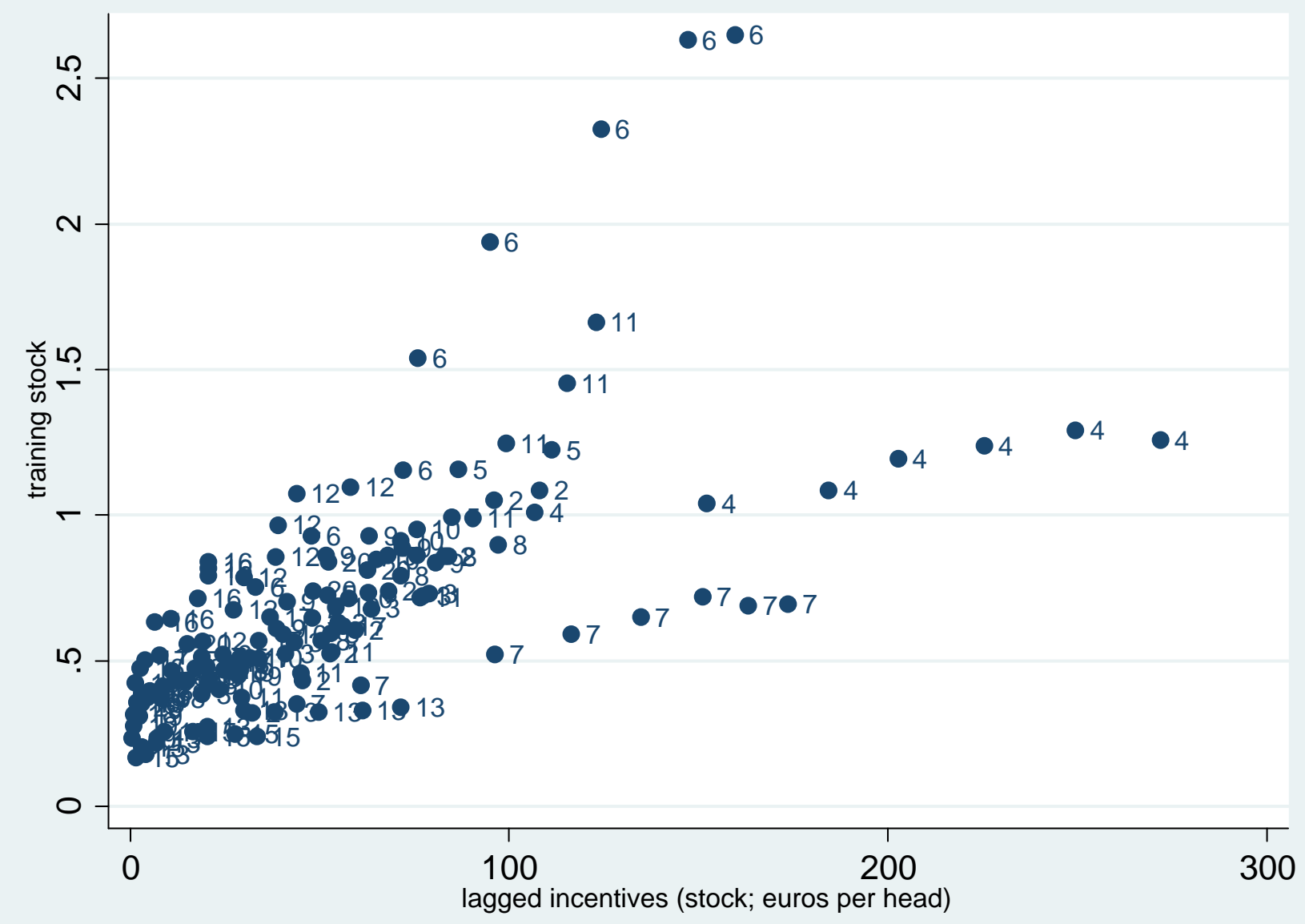


Figure 3. Marginal returns to a week of training

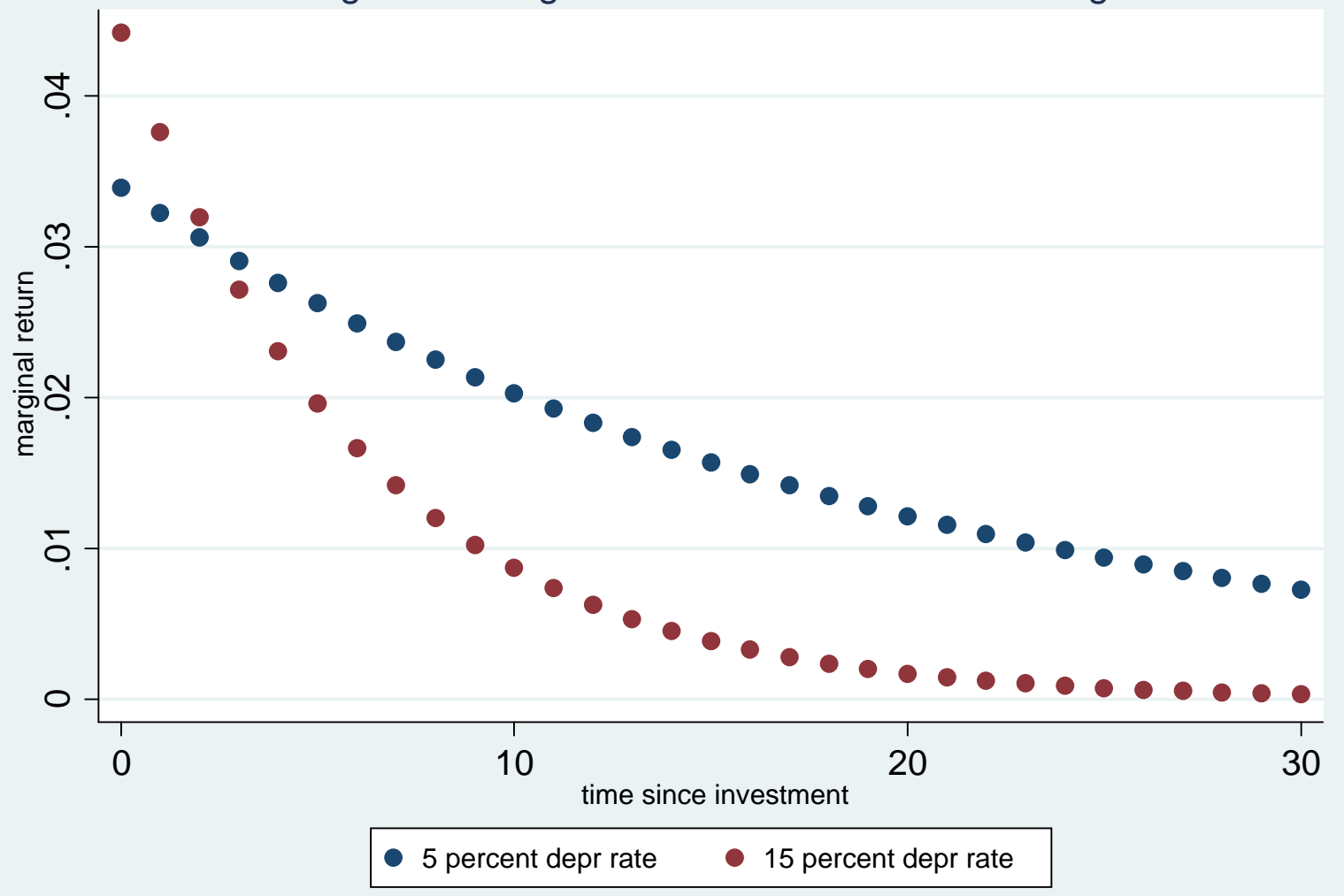


Figure 4. Marginal returns to a week of training; depr. rate:0.15

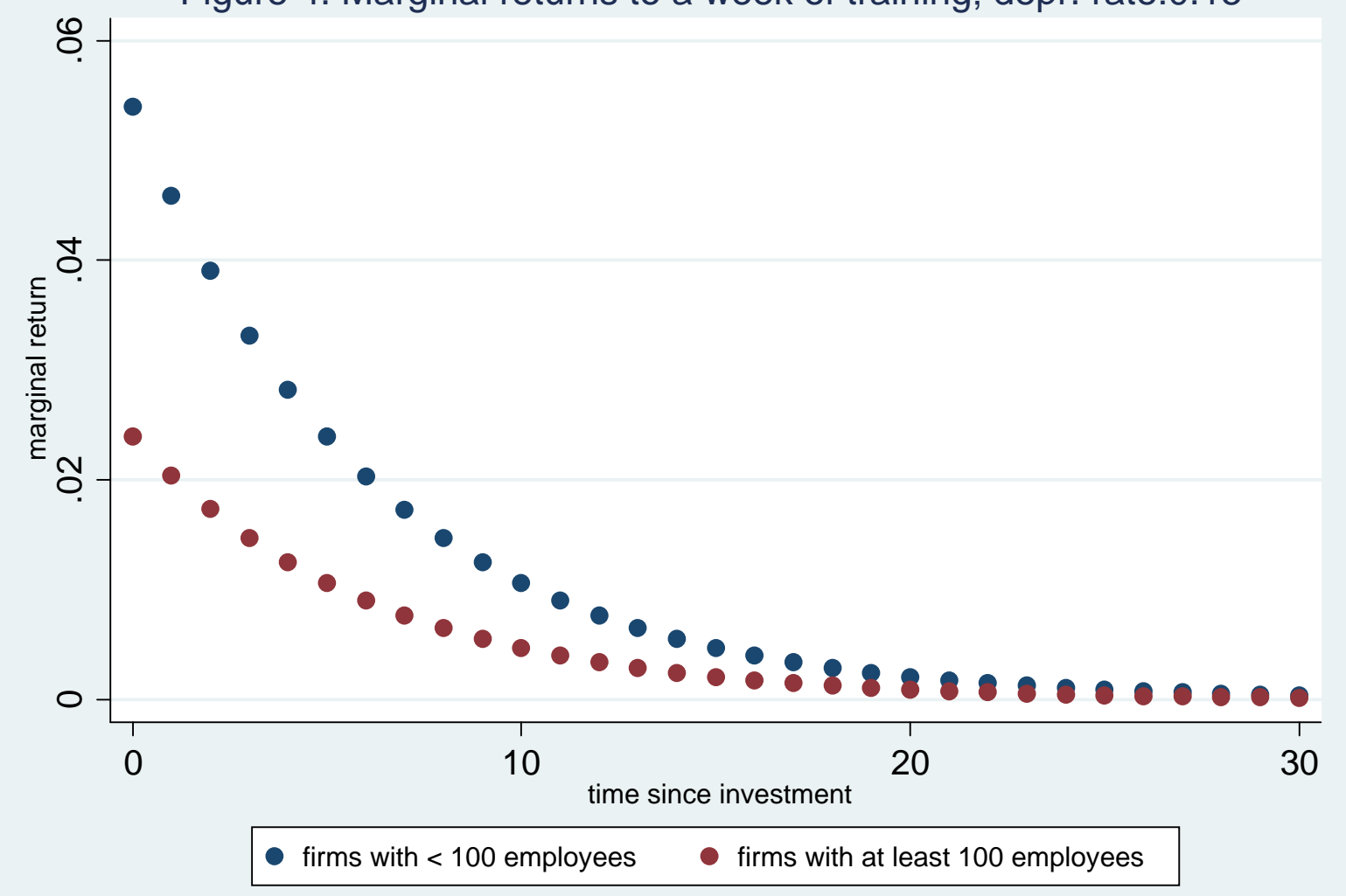

